\title{
The Evaluation of Clinical and Laboratory Findings of Pediatric Patients Applying with Tick Exposure
}

\author{
Kene Tutunması ile Başvuran Çocuk Hastaların Klinik ve \\ Laboratuvar Bulgularının Değerlendirilmesi
}

\author{
Ayça Kömürlüoğlu', Kamile Arıkan², Eda Karadağ Öncel ${ }^{2}$, Ateş Kara², Mehmet Ceyhan², Ali Bülent Cengiz² \\ ${ }^{1}$ Clinic of Pediatric Health and Diseases, Gurun State Hospital, Sivas, Turkey \\ ${ }^{2}$ Department of Pediatric Health and Diseases, Hacettepe University School of Medicine, Ankara, Turkey
}

\begin{abstract}
Objective: Crimean-Congo hemorrhagic fever (CCHF) is the most widespread, tick-borne viral disease affecting humans. CCHF first emerged in Turkey in 2002, and the prevalence of the disease has been found to be increased. Central Anatolia Region is endemic for the disease where sporadic cases or even outbreaks are being observed every year. The study was aimed to evaluate sociodemographic, clinical and laboratory parameters of children admitted due to tick bite and prediagnosis of CCHF and to discuss necessity of repeated blood sampling in asymptomatic cases.
\end{abstract}

Material and Methods: Between January 2014 and December 2016, hospitalized or outpatient pediatric cases ( $<18$ years) whom had tick bite in the Infectious Diseases Unit of Hacettepe University İhsan Doğramacı Children's Hospital were enrolled in the present study. Gender, age, contact region with tick, physical examination and laboratory findings of cases and occurence of CCHF were evaluated.

Results: In this study, 74 female (45.4\%), 89 male (54.6\%), a total of 163 cases were evaluated. The mean age of our cases was $7.49 \pm 3.9$ years. The most common admission was seen in the month of August. Tick was frequently removed from the region of the head and neck (56.1\%). Among patients 6 of whom diagnosed CCHF and discharged without any complication. In patients without CCHF (90.4\%) had any symptoms during follow-up and most of them (92.3\%) had normal laboratory findings on admission, 3 and 7-10 days. Symptoms such as fever, malaise, vomiting, abdominal pain, headache and rash was significantly common in patients with CCHF (all of them $p<0.001$ ) and they had at least one abnormal laboratory parameter on admission.
Özet

Giriş: Kırım Kongo kanamalı ateşi (KKKA), insanlarda görülen en sık kene ilişkili hastalıktır. KKKA Türkiye'de ilk olarak 2002 yılında görülmüş ve prevalansı giderek artmıştır. Orta Anadolu hastalık için endemiktir ve her yıl sporadik olgular ya da salgınlar görülebilmektedir. Bu çalışmada kene tutunması şikayetiyle hastanemize başvuran çocuk hastaların demografik özelliklerinin belirlenmesi, klinik bulgularının incelenmesi ve laboratuvar sonuçlarının değerlendirilmesi, asemptomatik olgularda erken dönemde laboratuvar tetkiklerinin gerekliliğinin tartışıması amaçlanmıştır.

Gereç ve Yöntemler: Ocak 2014-Aralık 2016 tarihleri arasında Hacettepe Üniversitesi İhsan Doğramacı Çocuk Hastanesi'ne kene ısırı̆ı şikayetiyle ayaktan başvuran çocuk hastalar ( $<18$ yaş) bu çalışmaya dahil edildi. Cinsiyet, yaş, kenenin tutunduğu bölge, fizik muayene ve laboratuvar bulguları ve KKKA meydana gelme durumu değerlendirildi.

Bulgular: Bu çalışmada 74 (\%45.4)'ü kız, 89 (\%54.6)'u erkek olmak üzere toplam 163 olgu değerlendirildi. Olguların ortalama yaşı $7.49 \pm 3.9$ yıldı. En sık başvuru Ağustos ayında görüldü (\%19). Kene sıklıkla baş-boyun bölgesinden çıkarılmıştı (\%56.1). Bu hastalardan altısı KKKA tanısı aldı ve hepsi komplikasyonsuz olarak taburcu edildi. KKKA gelişmeyen hastaların \%90.4'ünde takip boyunca herhangi bir semptom görülmedi ve bunların büyük kısmının (\%92.3) başvuru, üçüncü ve 7-10. günlerde laboratuvar bulguları normaldi. Ateş, halsizlik, kusma, karın ağrısı, başağrısı ve döküntü gibi semptomlar KKKA olan hastalarda istatistiksel olarak daha sıktı (tüm değerler için $p<0.001$ ) ve hepsinin başvurudaki laboratuvar parametrelerinden en az biri anormaldi. 
Conclusion: Physical examination must be done carefully in patients presenting with tick bite and tick should be removed with an appropriate tecnique. Selected patients without any alarming symptoms may be follow-up without blood tests due to increased costs.

Keywords: Tick bite, Crimean-Congo hemorrhagic fever, symptoms, laboratory

\section{Introduction}

Viral hemorrhagic fever (VHF) infections are clinical syndroms generated by different viruses in humans that progress with fever and hemorrhage. Symptoms such as diarrhea, muscle pain, cough, penumonia, encephalopathy, and hepatitis are seen during the course of this group of infections. Crimean-Congo Hemorrhagic Fever (CCHF) is a fatal disease with a mortality rate of 5-30\%, whose agent is an RNA virus defined in the Nairovirus species in the family Bunyaviridea (1). The disease, for the first time in history, was seen in summer in the years of the Second World War among the Soviet soldiers helping rural works in Western Crimea and affected more than 200 people (2). The disease was determined to have transmitted by ticks and was referred to as Crimean Hemorrhagic Fever. The first case in Turkey was detected in Tokat province located in Kelkit Valley in 2002 (3). CCHF is seen endemically in the northeastern part (Tokat, Amasya, Sivas, Gümüşhane, Yozgat and Çorum) in Turkey. A total of 9069 CCHF cases were reported between the years 2002 and 2014, and $4.8 \%$ of these cases were lost (4-6).

CCHF virus circulates within the tick-vertebrata-tick cycle in nature and even though the virus is isolated from 30 types of tick, the most important tick types proved to be vectors today belong to the Hyalomma species $(7,8)$. It is seen in studies that Hyalomma marginatum, Hyalomma anatolicum and Dermacentor marginatus have been detected in all geographical regions (9). CCHF virus is transmitted to humans by infected ticks that suck blood, through contact to blood or bodily fluids of CCHF patients or viremic animals or by crushing the infected ticks with bare hands. The course of the disease typically has four stages including incubation, prehemorrhagic, hemorrhagic and convalescence. The incubation period of the disease ranges from 3 to 14 days depending upon way of transmission, viral load and the state of host's immunity. The prehemorrhagic stage starts with complications such as sudden fever after the incubation period, extensive muscle pain, severe headache, cold, shivering, nausea-vomit, diarrhea, redness on the face and conjunctiva, photofobia and maculopapular skin eruption $(1,9,10)$. Symptoms such as subcutaneous bleeding like petechial, purpura and ecimosis, and gingival, nasal, vaginal, gastro-intestinal, urinary, pulmonary
Sonuç: Kene tutunması ile başvuran hastalarda fizik muayene dikkatli bir şekilde yapılmalı ve kene uygun bir teknikle çıkarılmalıdır. Ciddi semptomu olmayan seçilmiş hastalar artan maliyetler nedeniyle kan tetkikleri alınmadan izlenebilir.

Anahtar Kelimeler: Kene tutunması, Kırım Kongo kanamalı ateşi, semptomlar, laboratuvar bulgular

and cerebral bleeding that belong to the hemorrhagic stage are seen during progressive periods of the disease $(1,11,12)$. Impaired consciousness, agitation, hepatorenal failure, respiratory distress, disseminated intravascular coagulopathy, shock and coma can develop and progress into mortality in severe cases (13). In laboratory findings, increase in levels of thrombocytopenia, leucopenia, aspartate aminotransferase (AST), alanine aminotransferase (ALT), lactate dehydrogenase (LDH) and creatine phosphokinase (CK) and prolongation in prothrombin time (PT), active partial thromboplastin time (aPTT) and in other coagulation tests are observed. Decrease in fibrinogen level and increase in fibrin catabolites can be encountered $(1,14,15)$. Mortality is generally observed on the second week of clinical findings. Cases with a mild to moderate clinical course recover in 9-10 days. Full recovery process usually takes place in a time period of 2-6 weeks. Sequel is not usually observed in cases that recover (14). Definitive diagnosis of the disease is made by reverse transcriptase polymerase chain reaction (PCR) or by virus isolation in the early period and serologically by enzyme-linked immunosorbent assay (ELISA) and by the detection of specific $\lg M$ antibodies through indirect immunofluorescence antibody (IFA) after the seventh day of the disease (9).

Number of patients applying to emergency services due to tick exposure increases in spring and summer months. Basic approach in patients with tick exposure includes the appropriate removal of the tick from the body and clinically following the case closely. The aim of this study was to determine the demographic characteristics of pediatric patients applying to our hospital with tick exposure, examine clinical findings, evaluate laboratory results and discuss the necessity of laboratory tests in the early period in asymptomatic cases.

\section{Materials and Methods}

The files of 163 patients applying to the Pediatric Infectious Diseases Outpatient Clinic of Hacettepe Üniversitesi İhsan Doğramacı Children's Hospital between 01.01.201431.12.2016 for tick exposure were retrospectively examined after approval from Non-invasive Clinical Research Ethics Board had been received. Demographic characteristics of the patients, application date, county/province of the patient, complaints on application, the area of tick exposure, the time 
elapsed between tick exposure and application to hospital, physical examination and clinical findings, full blood count on admission, third, and 7-10 days, blood biochemistry, hemorrhage parameters and state of admission to hospital were recorded.

A thorough physical examination was performed in all cases that applied with the complaint of tick exposure and all areas of the body were inspected. In cases with tick on their bodies, the tick was removed with a curve-tipped forceps, and wound cleaning was carried out with antiseptic solution. Patients applying due to tick exposure whose full blood count, AST, ALT, LDH, CK, aPTT, PT and international normalized ratio (INR) values were sent were retrospectively reviewed. After initial examination on the day of application, the patients were re-evaluated on days 3,7-10. Patients with suspected CCHF were admitted to Pediatric Infectious Diseases Unit. Viral genom and/or CCHF immunoglobulin M antibody was investigared with real-time PCR (RT-PCR) by having sent blood samples from suspected cases to Public Health Agency of Turkey in Ankara.

After having received the approval of the ethics board, the data of all patients included into the study was examined retrospectively from computer records. Anemia, leucopenia and thrombocytopenia were defined as being under the lower limit of hemoglobin, leucocyte and thrombocyte count with regard to age groups. When ALT, AST, CK, LDH, aPTT, INR values were twofolds the laboratory reference values, they were evaluated as high ALT, AST, CK, LDH and prolonged INR and APTT.

SPSS (Statistical Package for Social Sciences) for Windows 21 was used for statistical analyses. Conformity of the variables to normal distribution was examined through visual (histogram and probability graphics) and analytic methods (Kolmogorov-Smirnov/Shapiro-Wilk tests). Defining statistics were carried out by number and percentage for categorical variables, by giving mean \pm standard deviation for continuous variables with normal distribution and median (minimum-maximum) for continuous variables without normal distribution. Pearson Chi-Square test was used for the comparison of categorical variables. The variabes were compared between the groups using Student-T test and Mann-Whitney $\mathrm{U}$ test. $P$ value below 0.05 was considered statistically significant.

\section{Results}

When a total of 163 patients applying with tick exposure for a period of 3 years were retrospectively reviewed, it was concluded that six of the patients were admitted to Pediatric Infectious Diseases Unit with a preliminary diagnosis of CCHF and 157 patients were followed as outpatients and CCHF did not develop. Seventy-four (45.4\%) of the patients were fema- les and 89 (54.6\%) were males; mean age was $7.49 \pm 3.9$ years (minimum 1.5-maximum 18 years). When the patients were evaluated as regards age groups, forty-nine (30.1\%) patients were between $1-5$ years, 85 (52.1\%) were between $6-10$ years and 29 (17.8\%) were 10 and over.

It was confirmed that seventy (42.9\%) of the applications were made in 2014, 48 (29.4\%) in 2015 and 45 (27.7\%) in 2016. Thirty-one (19\%) applications were determined to have been made in August (Figure 1). It was seen that the majority of applications for tick exposure were from Ankara and its counties $(n=142,87.1 \%)$. Figure 2 shows the regional distribution of the applications.

The site of tick exposure of 123 out of 163 cases could be reached in patient records. Tick exposure was mostly encountered in the head-neck region $(n=69,56.1 \%)$. The tick

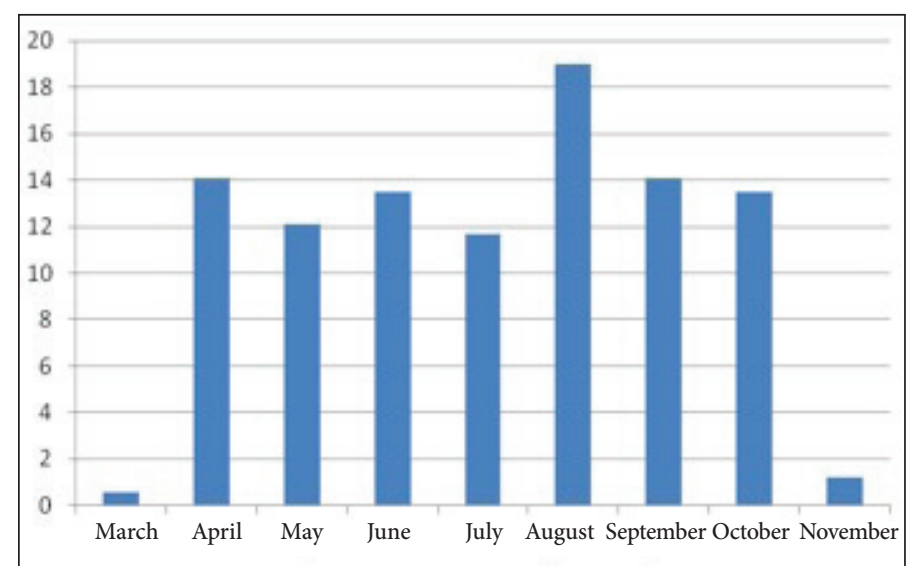

Figure 1. Case distribution according to months (\%).

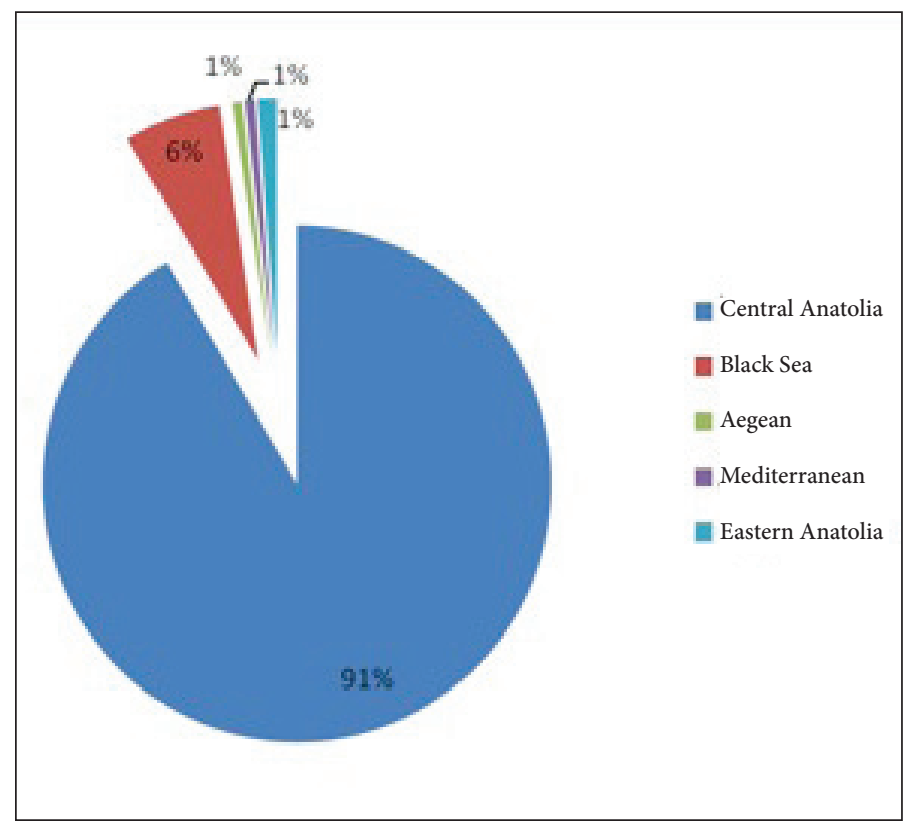

Figure 2. Regional distribution of the cases applying with tick exposure. 
Table 1. Distribution of tick exposure sites according to age groups

\begin{tabular}{|l|c|c|c|c|c|c|}
\hline Age (year) & $\begin{array}{c}\text { Head-Neck } \\
\mathbf{n}(\%)\end{array}$ & $\begin{array}{c}\text { Truncus } \\
\mathbf{n}(\%)\end{array}$ & $\begin{array}{c}\text { Upper extremity } \\
\mathbf{n}(\%)\end{array}$ & $\begin{array}{c}\text { Axilla } \\
\mathbf{n}(\%)\end{array}$ & $\begin{array}{c}\text { Groyne-genital } \\
\text { region n (\%) }\end{array}$ & $\begin{array}{c}\text { Lower extremityn } \\
\text { (\%) }\end{array}$ \\
\hline $1-5$ & $18(52.9)$ & $4(11.8)$ & $5(14.7)$ & $3(8.8)$ & $2(5.9)$ & $2(5.9)$ \\
\hline $6-10$ & $42(61.8)$ & $9(13.2)$ & $2(2.9)$ & $3(4.4)$ & $9(13.2)$ & $3(4.4)$ \\
\hline$>10$ & $9(42.9)$ & $3(14.3)$ & $2(9.5)$ & $0(0)$ & $3(14.3)$ & $4(19)$ \\
\hline Total & $69(56.1)$ & $16(13)$ & $9(7.3)$ & $6(4.9)$ & $14(11.4)$ & $9(7.3)$ \\
\hline
\end{tabular}

was re moved from the scalp in 26 of these patients, behind the ear in 27, from the neck in 14 and from the cheek in 2. Other frequent sites of tick exposure were truncus $(n=16$, $13 \%)$ and groyne and genital region ( $n=14,11.4 \%)$. Table 1 demonstrates the age groups of the cases and tick exposure sites. Head-neck region involvement was found to be higher in small age groups and involvement in truncus, groyne-genital region and lower extremity was more frequently observed in cases > 10 years of age; however, a statistically significant difference was not found between tick exposure sites as regards the age groups $(p=0.17)$.

Although tick typing is not recommended in routine practice, ticks belonging to the Hyalomma species were detected in 22 and ticks belonging to the Rhipicepholus species were found in 3 of the 25 cases sent to Public Health Agency of Turkey for tick typing. The elapsed time between tick exposure and application to our hospital was $1 \pm 2.08$ days (minimum same day- maximum 10 days). One hundred and twenty (73.6\%) of the patients applied to hospital the day the tick was removed, and the tick was removed by the patient him/herself or by emergency service doctors on the day of application. Eight patients (4.9\%) applied to hospital on the first day of tick removal, 2 patients (1.2\%) on the second day, 16 patients $(9.8 \%)$ on the third day, 4 patients $(2.5 \%)$ on the fourth day, 12 patients $(7.4 \%)$ on the seventh day and 1 patient $(0.6 \%)$ on the tenth day.

Six of the 163 cases included into the study received CCHF diagnosis, of whom 3 were females (50\%) and 3 were males (50\%). Mean age was $11.3 \pm 5.03$ years (minimum 3 years 9 months, maximum 17 years 8 months). The patients applied to hospital in May, June, August, October and November. While $\mathrm{CCHF}$ is seen more frequently between the months April and October, it was regarded interesting for one case, age 6, from Çorum to have applied in November. Leading provinces where the disease is extensively encountered include Erzurum, Erzincan, Gümüşhane, Bayburt, Tokat, Yozgat, Sivas, Amasya, Çorum, Çankırı, Bolu, Kastamonu, and Karabük. In our study, two patients were from Çankırı, 1 from Kastamonu, 1 from Mardin, 1 from Çorum, and 1 from Ankara Kızılcahamam.
Even though Mardin is a province where these cases are not frequently seen, CCHF was diagnosed in a 15-year-old patient from Mardin in August 2014. This situation can be explained by the recent expansion of the area the disease is seen and by the reports of sporadic cases from nearly every corner of our country. T negativity and bradycardia were confirmed on electrocardiography during ribavirin use in one patient from Mardin and the patient recovered after ribavirin use was stopped. It was found out that patients from Çankırı (aunt) and Kastamonu (grandmother) were that patient's relatives treated for CCHF.

Tick exposure site in three patients was recorded as headneck region. Along with not recommending tick typing in routine practice, tick type in two patients was detected as Hyallomma spp. The mean time elapsed between tick exposure/removal to hospital application was $3.83 \pm 1.94$ days (minimum same day maximum 7 days) .

$90.4 \%(142 / 157)$ of the patients who applied with tick exposure but in whom CCHF did not develop did not have an active complaint during application. All of the patients in whom CCHF developed had at least one complaint during application. Table 2 shows the most frequently observed complaints during application in groups in whom CCHF developed and did not develop. Fever, malaise, vomiting, headache and rash was seen statistically more in patients in whom CCHF developed ( $p<0.001$ for all values). Laboratory tests on application, day 3 and days 7-10 of the 131 patients out of 142 (92.3\%) who were asymptomatic during application and did not develop CCHF were found normal. Laboratory examinations on application, day 3 and days 7-10 of the patients who applied with tick exposure and did not develop CCHF were normal in $89.8 \%(n=141)$. While at least one anomaly was detected in cases with CCHF diagnosis $(6 / 6)$, anomaly in laboratory findings in the group that did not receive CCHF diagnosis was present in only $10.2 \%$ of the patients (16/157). Anemia was seen in two of the patients (33.3\%) that developed CCHF, leucopenia in 3 (50\%) and thrombocytopenia in 5 (83.3\%). AST elevation was detected in 4 patients (66.6\%), ALT elevation in 2 (33.3\%), CK elevation 
Table 2. Symptoms and findings in patients applying with tick exposure

\begin{tabular}{|c|c|c|c|}
\hline Clinical findings & $\begin{array}{l}\text { Cases with CCHF diagnosis } \\
(n=6)\end{array}$ & $\begin{array}{l}\text { Cases without CCHF diagnosis } \\
\qquad(n=157)\end{array}$ & $\mathbf{p}$ \\
\hline Fever & $6(100)$ & $8(5)$ & $<0.001$ \\
\hline Nasal discharge & $1(16.6)$ & $2(1.2)$ & 0.1 \\
\hline Stomachache & $4(66.6)$ & $4(2.4)$ & $<0.001$ \\
\hline Nose bleed & - & $2(1.2)$ & 0.78 \\
\hline Vomiting & $5(83.3)$ & $6(3.8)$ & $<0.001$ \\
\hline Malaise & $5(83.3)$ & $3(1.9)$ & $<0.001$ \\
\hline Petechia/purpura & $3(50)$ & - & $<0.001$ \\
\hline
\end{tabular}

Table 3. Laboratory results of the patients on application

\begin{tabular}{|c|c|c|c|}
\hline Laboratory data & $\begin{array}{l}\text { Cases with CCHF diagnosis } \\
\qquad(n=6)\end{array}$ & $\begin{array}{l}\text { Cases without CCHF diagnosis } \\
\qquad(n=157)\end{array}$ & $\mathbf{p}$ \\
\hline $\mathrm{Hb}(\mathrm{g} / \mathrm{dl})^{\mathrm{a}}$ & $12.4 \pm 0.97$ & $12.7 \pm 1$ & 0.49 \\
\hline Thrombocyite $\left(\times 10^{3} / \mu \mathrm{L}\right)$ & $93.4 \pm 47.9$ & $317 \pm 76.4$ & $<0.001$ \\
\hline $\operatorname{AST}(\mathrm{U} / \mathrm{L})^{\mathrm{a}}$ & $110 \pm 76.4$ & $34.5 \pm 34.2$ & $<0.001$ \\
\hline $\mathrm{CK}(\mathrm{U} / \mathrm{L})^{\mathrm{b}}$ & $324(47-1010)$ & $116(8-22680)$ & 0.86 \\
\hline aPTT(sn) ${ }^{\mathrm{a}}$ & $33.1 \pm 6.2$ & $29.6 \pm 21.3$ & 0.72 \\
\hline $\mathrm{INR}^{\alpha}$ & $1.22 \pm 0.31$ & $1.08 \pm 0.089$ & 0.003 \\
\hline
\end{tabular}

in $4(66.6 \%), \mathrm{LDH}$ elevation in $3(50 \%)$, and two patients (33.3\%) had prolonged INR and one had prolonged aPTT. While leucopenia was ecountered in two (1.2\%) and anemia in $1(0.6 \%)$ patient in the group that did not develop CCHF, thrombocytopenia was not seen in any cases. AST elevation was seen in two (1.2\%), ALT elevation in $3(1.9 \%)$, and LDH and CK elevation in 5 patients (3.1\%) each. INR prolongation was present in eight (5\%) and aPTT elevation was seen in $2(1.2 \%)$ patients. Table 3 demonstrates the laboratory results of the cases in both groups.

Diagnosis was established in $3(50 \%)$ of the 6 patients that received CCHF diagnosis by RT-PCR and by immunoglobulin $M$ antibody positivity in the remaining 3 patients. All of these patients were discharged without sequel.

\section{Discussion}

Demographic characteristics, clinical features and laboratory results of pediatric patients that applied to hospital with tick exposure were evaluated in our study. Together with print and mass media coverage of tick exposure and related deaths, serious concern, sensitivity and awareness have developed in our public. As a consequence, application to emergency services or infectious diseases outpatient clinics for tick exposure have risen in recent years in comparison to past years (9).

Climate change is one of the factors increasing prevalence in tick-born disease. Many cases occur in spring and summer months. It has been reported in studies conducted in our country that the incidence of ticks rise with the increase in temperature, show seasonal characteristics and occur between 
the months May and September (16-21). These are the months when children go more frequently to countrysides and picnic areas, and thus, it is the period when contact risk with ticks is the highest. Emergency service applications due to tick exposure in our study were made mostly in August (19\%) and application months of the patients were found similar to the data in the literature.

Tick bite cases are encountered at every age and in both genders. While the rate of female cases has been found as $56 \%$ in a study by Akarsu et al. carried out in pediatric age group (22), this rate has been determined as $68 \%$ in a study by Taşkesen et al. (23). Moreover, the rate of male cases has been respectively confirmed as $64 \%$ and $59 \%$ in studies by Al et al. (16) and Kandiş et al. (19). In our study, $45.4 \%$ of the cases were females and $54.6 \%$ were males, and male cases were found to be slightly higher.

While locating the tick in the visible parts of the body is easier, noticing the tick in non-visible parts of the body could be more difficult. Therefore, it should be kept in mind that there may be more than one region with the tick and all regions of the body should be examined vigilantly. The most frequent tick exposure sites in the study by Duman et al. have been reported as head-neck with $50 \%$, truncus with $28.3 \%$ and arms and legs with $21.7 \%$ (20). Ticks have been encountered the most on legs (43\%), truncus $(12 \%)$ and in the axillary region (8) in the study by Sümer et al. (24) The most frequent tick exposure site in our study was the head-neck region $(56.1 \%)$. While head-neck involvement has been found more frequent in small age groups in the study by Duman et al, lower extremity and foot involvement have been reported to be higher in older age groups (19). While head-neck involvement was higher in small age groups in our study, it was realized that truncus, lower extremity and groyne-genital region involvement was higher in older age groups; however, the results were not found to be statistically significant $(p=$ 0.17). These results are crucial in terms of demonstrating the primary regions to be attentive to while looking for ticks in different age groups. The high rate of head-neck involvement shows that standard measures (boots and thick socks) are not sufficient to protect children from tick exposure and that leaving the children in this age group on the ground in the countryside and picnic areas is extremely risky.

It has been indicated that ticks belonging to the Hyalomma species are the most frequently detected of all in studies from Turkey (9). 55.6\% Hyalomma species, $15.4 \%$ Ixodidae species and $12.5 \%$ Rhiphicephalus species were detected in the ticks whose species typing was made in the study by Duman et al. In our study, ticks from Hyalomma species were confirmed in 22 cases and ticks from Rhiphicepholus species were confirmed in 3 .
It has been reported in studies regarding children with CCHF from our country or others that symptoms such as fever, nausea, vomiting, malaise, headache, hemorrhage, muscle pain and jaundice are seen during application and that conjunctival hyperemia and fever are the most frequently observed signs in physical examination $(25,26)$. Similar to the literature, fever, vomiting, malaise, headache, and findings of respiratory tract infection were seen during application to hospital in our study, and petechia-purpura-ecchymosis and maculopapular skin eruption were seen at a lower late. Mortality in CCHF cases in our country is around 5\% $(4-6,27)$. All of the patients admitted to the pediatric infectious diseases unit with the diagnosis of CCHF were discharged with full recovery and no mortality was observed. There are studies in the literature indicating lower mortality in the pediatric age group in comparison to the adult age group. No fatal cases were seen in a study by Tezer et al. including $31 \mathrm{CCHF}$ cases under the age of 16 (28). There were no cases lost in a study by Kızılgün et al. including $41 \mathrm{CCHF}$ patients between the ages of 1 and 17 (29). Serum chemokines levels of pediatric patients that received CCHF diagnosis have been found lower than those of the adults in a multicenter study (30). Factors like hasty transfer of the pediatric age group to a health center and their lower chemokines response may explain low mortality in the pediatric age group.

Thrombocytopenia and leucopenia, elevated liver enzymes, CK, LDH and coagulation parameters can be detected in CCHF cases. When Güngör et al. analyzed the full blood count and biochemical parameters of nine pediatric patients with CCHF disease, $55.5 \%$ of the patients had anemia and leucopenia, $77.7 \%$ had thrombocytopenia, $44.4 \%$ had prolonged PT, 66.6\% had elevated CK, 77.7\% had elevated AST and ALT, and $88.8 \%$ had elevated LDH (31). Yardan et al. have detected thrombocytopenia in $29.2 \%$ of patients with CCHF diagnosis, leucopenia in $8.3 \%$, leukocytosis in $6.8 \%$ and anemia in $29.2 \%$ (32). Duksal et al. have detected thrombocytopenia in $80.6 \%$ of the cases, leucopenia in $70.8 \%$, neutropenia in $50 \%$, elevated AST in $73.6 \%$ elevated ALT in $26.4 \%$, elevated in LDH in $71.6 \%$, elevated CK in $68.1 \%$, prolonged PT in $54.2 \%$ and prolonged aPTT in $52.8 \%$ in their study including 72 pediatric patients with CCHF diagnosis in Sivas (33). In our study, anemia was found as $33.3 \%$, leucopenia as $50 \%$, thrombocytopenia as $83.3 \%$, ALT elevation as $33.3 \% \mathrm{~m}$ AST elevation as $66.6 \%$, CK elevation as $66.6 \%$, LDH elevation as $50 \%$, aPTT prolongation as $16.6 \%$ and INR elevation as $33.3 \%$ in CCHF patients, and our data was established to show similarity with the literature.

There is no specific treatment of CCHF. World Health Organisation (WHO) recommends the use of oral and intravenous ribavirin(34). The basis of treatment in this disease consists supportive care. When necessary, the patients should 
be given thrombocyte suspension, freshly frozen plasma and erythrocyte suspension; respiratory, dialysis, and parenteral nutrition support should be provided; and fluid-electrolyte balance should be monitored (30). In our study, two of the 6 patients receiving CCHF diagnosis were given ribavirin and the remaing 4 were followed with supportive care. T wave negativity and bradycardia were seen during ribavirin use in one patient.

Due to the fact that duration of tick exposure is one of the most important factors in determining transmission in diseases transmitted by ticks, the tick should be immediately detected and removed. The tick was realized within the first 24 hours post-contact in a majority of the cases $(73.8 \%)$ in our study group and the patients applied to hospital. The reason for early detection and hospital application is the increase in public sensitivity thanks to the warnings made in printed and mass media and the fact that families look for ticks during bath time or while helping their children change clothes especially after returning from the countryside, and hence detect the tick at an early period. This situation can be regarded as a sign that these publications and broadcasts have increased awareness in the public.

No symptom and finding was detected upon application to hospital in 142 of the patients with tick exposure complaint. All laboratory examinations were found within normal limits in $131(92.3 \%)$ of these patients and laboratory tests were repeated on application, on days 3,7-10 and no problem was observed in the follow-up of these patients. In the study by Duman et al., anomaly was confirmed in $27.3 \%$ of the laboratory tests of the patients applying with tick exposure, and it was seen that there was no correlation with clinical findings (19). In the study by Oğuz et al. where 84 tick exposure cases that applied to the pediatric emergency service were examined, clinical and laboratory anomaly was not detected in any of the patients (20). Anomaly was not determined in a majority of laboratory parameters of every patient who did not have clinical findings and applied with tick exposure. These results made us think that follow-up with laboratory tests is not necessary in every patient who does not have any clinical finding. Moreover, routine laboratory followups without clinical findings lead to unnecessary increase in health expenses, and false negative results cause stress in the physician and the family. It is considered that clinical follow-ups on specific days, informing the families regarding symptoms that could develop and explaining the necessity of urgent hospital application in the event of symptom development are more crucial.

In conclusion, physical examination of the cases applying with the complaint of tick exposure should be attentively conducted, the tick should be removed with an appropriate technique, and the patients should be followed up in outpatient clinics by stating that they need to apply to hospital again if there is any complaint including sudden rise in body temperature, headache and muscle pain and malaise within ten days. It is taken into account that laboratory examinations from every case that does not have any additional complaint other than tick exposure increase the cost and do not provide extra profit in patient follow-up.

Ethics Committee Approval: Ethics committee approval was received for this study from Hacettepe University Medical Faculty's local ethics committee.

Informed Consent: Written informed consent was not received due to the retrospective nature of this study.

Peer-review: Externally peer-reviewed.

Author Contributions: Concept - EKÖ, KA; Design - AK, KA; Supervision - EKÖ, ABC, AK, MC; Data Collection and/or Processing - AK, KA; Analysis and/or Interpretation - KA, AK; Literature Review KA, AK; Writing - KA, AK; Critical Review - EKÖ

Conflict of Interest: No conflict of interest was declared by the authors.

Financial Disclosure: The authors declared that this study has received no financial support.

\section{References}

1. Ergonul O. Crimean-Congo hemorrhagic fever. Lancet Infect Dis 2006;6:203-14. [CrossRef]

2. Chumakov MP, Butenko AM, Chalunova NV, et al. New data on the virus causing Crimean haemorrhagic fever. Vop Virusol 1968; 13:377. [CrossRef]

3. Gözalan A, Esen B, Fitzner J, et al. Crimean-Congo haemorrhagic fever cases in Turkey. Scand J Infect Dis 2007;39: 332-6. [CrossRef]

4. Yilmaz GR, Buzgan T, Irmak $H$, et al. The epidemiology of CrimeanCongo hemorrhagic fever in Turkey, 2002-2007. Int J Infect Dis 2009;13:380-6. [CrossRef]

5. Leblebicioglu H. Crimean-Congo haemorrhagic fever in Eurasia. Int $\mathrm{J}$ Antimicrob Agents 2010;36:S43-6. [CrossRef]

6. Sunbul $M$, Leblebicioglu $H$, Fletcher $T E$, et al. Crimean-Congo haemorrhagic fever and secondary bacteraemia in Turkey. J Infect 2015;71:597-9. [CrossRef]

7. Kırdar S, Ertuğrul MB. Kırım-Kongo kanamalı ateşi. ADÜ Tıp Fak Derg 2009;10:45-52. [CrossRef]

8. Kırım Kongo Kanamalı ateşi bilimsel değerlendirme raporu. Ankara: Türk Tabipleri Birliği Yayınları, 2010;48.

9. Ser Ö, Çetin H. Kırım Kongo Kanamali Ateşi'nin güncel durumu . TAF Prev Med Bull 2016; 15:58-68. [CrossRef]

10. Whitehouse CA. Crimean-Congo hemorrhagic fever. Antiviral Res 2004; 64:145-60. [CrossRef]

11. Bente DA, Forrester NL, Watts DM, McAuley AJ, Whitehouse $C A$, Bray M. Crimean-Congo hemorrhagic fever: history, epidemiology, pathogenesis, clinical syndrome and genetic diversity. Antiviral Res 2013;100:159-89. [CrossRef] 
12. Vorou R, Pierroutsakos IN, Maltezou HC. Crimean-Congo hemorrhagic fever. Curr Opin Infect Dis 2007;20:495-500. [CrossRef]

13. Korkmaz M, Yıldırım Y, Özçelik H, Fadıloğlu Ç. Güncel bir sorun: KırımKongo kanamalı ateşi. Fırat Sağ Hiz Derg 2008;3:67-85.

14. Akın L. Kırım-Kongo kanamalı ateşi. Hacettepe Tıp Derg 2008; 39:13443. [CrossRef]

15. Öngürü P, Bodur H. Kırım Kongo kanamalı ateşi. J Exp Clin Med 2012; 29:175-81. [CrossRef]

16. Al B, Yıldırım C, Söğüt Ö, Yeşilkaya A. Batman Devlet Hastanesi Acil Servisine yedi ayda başvuran 39 kene ısırığının değerlendirilmesi. Akad Acil Tıp Derg 2008;7:40-3.

17. Arıkan I, Tıraş Ü, Saraçoğlu D, Taşar MA. Kene ısırı̆ı̆ı nedeniyle başvuran olguların değerlendirilmesi. Ege Tıp Derg 2009; 48:29-31. [CrossRef]

18. Kandiş $H$, Katırcı Y, Uzun H, Güneş Y, Geyik FM. Endemik bir bölgede kene ısırığı nedeniyle acil servise başvuran olguların demografik ve epidemiyolojik özellikleri. Düzce Tıp Dergisi 2010;12:18-23. [CrossRef]

19. Duman $M$, Inceboz T, Gençpınar $P$, Över $L$, Çelik D. Çocuk acil servisine kene tutunması yakınması ile başvuran olguların değerlendirilmesi. Turkiye Klinikleri J Med Sci 2013;33:164-71. [CrossRef]

20. Oğuz S, Korkmaz V, Kurt F, Tekin D, Suskan E. Çocuk acil servisinde kene tutunması: asemptomik olgularda laboratuvar gerekli mi? Turk Hij Den Biyol Derg 2015;72:109-14. [CrossRef]

21. Bucak $i H$, Temiz F, Tümgör $G$ ve ark. Üçüncü basamak merkezde 161 kene ısırı̆ı̆ vakasının değerlendirilmesi. J Pediatr Inf 2013;7:3-6. [CrossRef]

22. Akarsu S, Erensoy A, Durukan Tosun M, Cakıcı O, Yıldırmaz S. Kene tutunması ile başvuran olguların değerlendirilmesi ve bir Kırım-Kongo kanamalı ateşi olgusu. Çocuk Enfeks Derg 2008;2:137-47. [CrossRef]

23. Taşkesen M, Okur N, Taş MA. Kene ısırması nedeniyle başvuran 19 olgunun değerlendirilmesi. Dicle Tıp Derg 2008;35:110-3. [CrossRef]

24. Sumer A. Kene ısırığı nedeniyle Kaş Devlet Hastanesi Acil Servisine başvuran hastaların değerlendirilmesi. Kafkas Üniv Vet Fak Derg 2010;16:49-53. [CrossRef]
25. Ergonul O, Celikbas A, Dokuzoguz B, Eren S, Baykam N, Esener H. Characteristics of patients with Crimean-Congo hemorrhagic fever in a recent outbreak in Turkey and impact of oral ribavirin therapy. Clin Infect Dis 2004;39:284-7. [CrossRef]

26. Sharifı Mood B, Mardani M, Keshtkar Jahromi M, Rahnavardi M, Hatami $H$, Metanat M. Clinical and epidemiologic featuresof Crimean-Congo hemorrhagic fever among children andadolescents from southeastern Iran. Pediatr Infect Dis J 2008;27:561-3.

27. Yagci Caglayik D, Korukluoglu G, Uyar Y. Seroprevalence and risk factors of Crimean-Congo hemorrhagic fever in selected seven provinces in Turkey. J Med Virol 2014;86:306-14. [CrossRef]

28. Tezer H, Sucakli IA, Sayli TR ve ark. Crimean-Congo hemorrhagic fever in children. J Clin Virol 2010; 48:184-6. [CrossRef]

29. Kızılgun M, Ozkaya-Parlakay A, Tezer H, et al. Evaluation of CrimeanCongo hemorrhagic fever virus infection in children. Vector Borne Zoonotic Dis 2013;13:804-6. [CrossRef]

30. Arasli $M$, Ozsurekci Y, Elaldi NE, et al. Elevated chemokine levels during adult but not pediatric Crimean-Congo hemorrhagic fever. J Clin Virol 2015;66:76-82. [CrossRef]

31. Güngör O, Eroğlu EK, Güvan A, Kalaycı AK, Duru F. Çocuklarda Kırım Kongo kanamalı ateşi hastalığı. Antalya: 50. Milli Pediatri Kongresi özet kitapçı̆̆ı, 2006:281.

32. Yardan T, Baydın A, Başol N, Duran L, Sünbül M. Kene ısırması sonucu acil servise başvuran hastaların epidemiyolojik açıdan değerlendirilmesi. J Exp Clin Med 2009;26:153-6. [CrossRef]

33. Demir M, Duksal F, Doğan MT veark. Sivas, Cumhuriyet Üniversitesi'ne başvuran Kırım-Kongo Kanamalı Ateş'li çocukların klinik ve rutin laboratuvar testleri yanında immünolojik açıdan değerlendirilmesi.J Curr Pediatr 2015;13:13-20. [CrossRef]

34. World Health Organization (WHO). http://www.who.int/mediacentre/ factsheets/fs208/en/ Erişim tarihi: 20.01.2017 